\title{
A Quiet Revolution: The Birth of the Genetic Counselor at Sarah Lawrence College, 1969
}

\author{
Alexandra Minna Stern
}

Received: 25 June 2008 / Accepted: 31 July 2008 / Published online: 5 November 2008

(C) National Society of Genetic Counselors, Inc. 2008

\begin{abstract}
In 1969 Melissa Richter founded the first master's degree genetic counseling program in the country at Sarah Lawrence College in Bronxville, New York. This article examines the myriad factors that contributed to the birth of the genetic counselor and situates this historical watershed in its social, cultural, academic, and medical context. This article highlights Richter's prescience and path-breaking vision, evaluates the Sarah Lawrence program during the years of her directorship (1969-1972), and explores how this early foundation subsequently shaped the field of genetic counseling. Close attention is paid to the ethical issues that concerned Richter and their ongoing relevance to genetic health professionals today. This article is based on historical research in archives, consultation of primary sources, and oral history interviews with genetic counselors, geneticists, and allied professionals.
\end{abstract}

Keywords Genetic counseling · Genetic counseling programs · Ethics · History · Sarah Lawrence College · Melissa Richter

\section{Introduction}

In 1979 a small and dedicated group of genetic counselors founded the National Society of Genetic Counselors (NSGC; Heimler 1997). For genetic counselors, the creation of the NSGC provided the stamp of professional legitimacy, a secure job title, and a forum for graduates of

A. M. Stern $(\bowtie)$

Center for the History of Medicine, University of Michigan,

100 Simpson Memorial Institute, 102 Observatory,

Ann Arbor, MI 48109-0725, USA

e-mail: amstern@umich.edu genetic counseling programs in North America to further the goals of standardization and best practices. Over the past three decades, the NSGC has worked to expand the role of genetic counselors in the clinical setting, commercial sector, public health and education, and has served as a vibrant communication network for those in the profession and related fields.

From today's vantage point, this appears to be a fairly routine story of the professionalization of a new group of health care professionals with a distinctive portfolio of skills and responsibilities. However the emergence of the genetic counselor as a bona fide professional was neither inevitable nor smooth. Instead, this is a story of educational experimentation, audacious expectations and fortuitous timing that unfolded in tandem with dramatic shifts in American medicine and society. It is also a story whose principal actors were women, mainly white and middleclass, who sought to balance their fierce intelligence and independence with the demands of family life as they navigated the male physician-dominated realm of clinical genetics.

This article examines the birth of the genetic counselor in 1969 when Melissa Richter established the first master's degree (M.S.) program at Sarah Lawrence College. In the late 1960s, various social, scientific and educational factors converged to make the founding of this path-breaking program possible. These included: (1) the feminist health and civil rights movements; (2) the perspicacity and persistence of the program's founder, Melissa Richter; (3) Sarah Lawrence's unique educational mission and geographical location; and (4) advances in genetic technologies, above all prenatal diagnosis, which coincided with (5) the decriminalization of abortion, and (6) the increasing importance of bioethical principles such as patient autonomy. 
After exploring the dynamics that contributed to the conception of the genetic counselor, this article discusses the profile and characteristics of the intrepid students who joined the first cohorts of master's programs. It then reflects on some of the legacies and implications of this historical watershed for the field today. This article is based on research conducted in historical archives, the consultation of numerous primary sources, and the author's interviews with genetic counselors, geneticists, and allied professionals (Figs. 1, 2, and 3).

\section{Sarah Lawrence's "Special Baby": A child of the 1960s}

The late 1960s was a tumultuous time in America (Anderson 1996). The year 1968 saw the assassinations of Martin Luther King, Jr. and Robert F. Kennedy, the showdown at the Democratic Convention and race riots in Chicago, and rising opposition to the Vietnam War. The countercultural Woodstock Festival, the American Indian takeover of Alcatraz prison, and the Stonewall rebellion for gay liberation in New York City all occurred in 1969. Despite its suburban insulation in Bronxville (Westchester County), New York, Sarah Lawrence College was not immune to the unrest that rocked the country, especially college campuses, in the 1960s. In March 1969, Sarah Lawrence students occupied the main administration building for ten consecutive days to protest tuition increases and demand increased male enrollment (coeducation had begun

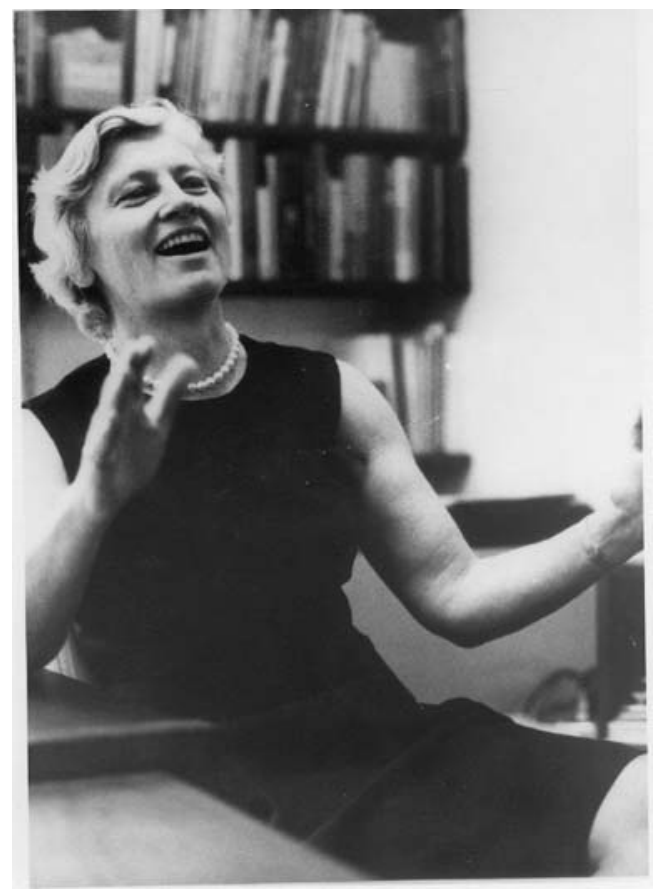

Fig. 1 A Vivacious Melissa Richter in Her Office at Sarah Lawrence College, ca. 1970. Source: Jacquelyn Mattfeld. Used with Permission.

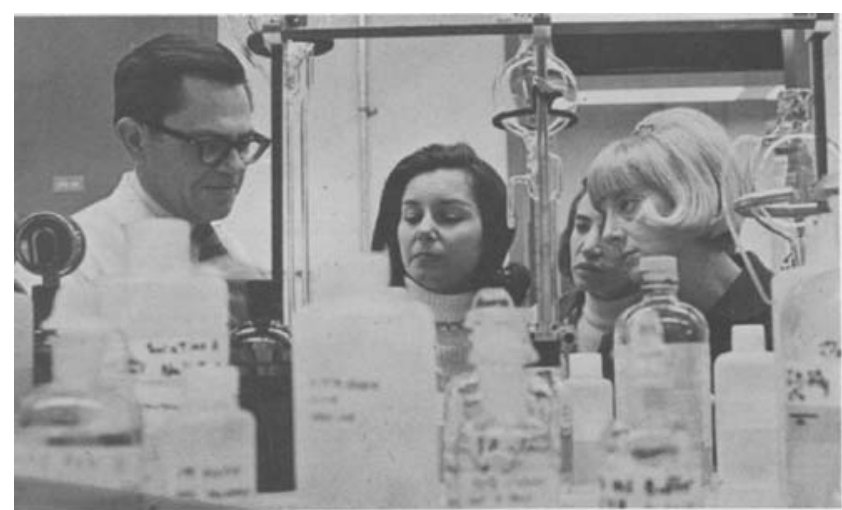

The curriculum combines class work and clinical work in neighboring teaching hospitals. In this picture, Dr. Harold M. Nitowsky, director of the Rose F. Kennedy Center for Research in Mental Retardation and Human Development, Albert Einstein College of Medicine, discusses a laboratory procedure with three human genetics students.

Fig. 2 Harold Nitowsky Teaching Sarah Lawrence Students at the Albert Einstein College of Medicine Hospital. Source: Human Genetics Graduate Program Brochure, ca. 1970, Sarah Lawrence College Archives. Used with Permission.

just 1 year earlier), racial and socio-economic diversification of the student body and faculty, and more community involvement in local service programs (Brady 1969; "Sarah Lawrence quiet" 1969).

It was during these turbulent months that Melissa Richter was laying the groundwork for Sarah Lawrence's genetic counseling program. The previous year she had begun to envision what she called "Sarah Lawrence's special baby" as one prong of a larger venture that included tracks for elementary health education and psychological training and counseling (Richter to Raushenbush 1969). At the time Richter was Dean of Graduate Studies and being groomed to direct Sarah Lawrence's Center for Continuing Education. Created in 1962, this center aimed to encourage women who had abandoned college education for reasons of marriage, motherhood, or work, to return to complete their bachelor's degree or to obtain a professional degree (Richter and

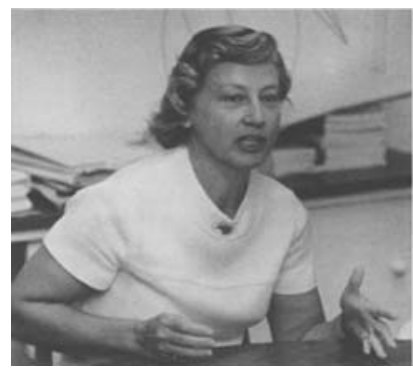

"If we were informed, if we projected the canse. quences of unrestricted reproduction and we can do this, then we could ... decide whether we want to control our population and if so how this con. trol can take place."

Fig. 3 Melissa Richter Expounding on the Need for Greater Genetic and Reproductive Control. Source: Richter, M. L. (1968b). The Effects of Overpopulation on Behavior: The Biologists' View. Sarah Lawrence Alumnae Magazine, 13. Sarah Lawrence College Archives, Gary Gladstone, Photographer. Used with Permission. 
Whipple 1972). The center's founder, Esther Raushenbush, Sarah Lawrence's president from 1965 to 1969 , described it as a "revolutionary step in the education of women" and viewed it as one component of a concerted effort to bring "equality of opportunity" to women and racial minorities (as cited in Richter and Whipple 1972, p. 7).

Richter believed that the Center for Continuing Education was the ideal home for a genetic counseling program, and would appeal to its core constituency, married women in their 30s with two to four children living at home. An adherent of difference feminism, or the idea that women deserved equality and rights because they differed in substantial and valuable ways from men, Richter imagined genetic counseling as suited distinctly for women "because they generally are more concerned with health and the preservation of life" (Richter 1968a, p. 2). A divorcee with no children, Richter was well poised to develop new career pathways for mature women whose lives were in professional and personal transition.

From her corner in Bronxville, Richter was able to take advantage of the spaces opened by the feminist and civil rights movements to appeal to a widening female workforce (Rosen 2000), specifically the segment comprised of "a new breed of middle class, at least partly college-educated" women (Bender 1969, p. 34). Clearly the moment was ripe for Richter's initiative. Even before the program was announced officially, a handful of enthusiastic women contacted Sarah Lawrence to inquire about application. Through publicity at a conference on genetic counseling sponsored by the March of Dimes and New York Medical Society's Infant Mortality Committee, word of mouth in and around New York City and Westchester County, and passing reference in The New York Times Sunday Magazine, a sympathetic audience learned about Richter's plans during spring 1969 (Bergsma 1970; Richter, "Notes on symposium" 1969c; Stock 1969). By the fall of that year, one dozen women had contacted Richter about enrollment (Heimler 2007). Ultimately, the interest was so great that Richter launched the program 1 year ahead of schedule, welcoming ten students in the fall and two more the following semester.

\section{The Perceptive and Persistent Melissa Richter}

Born in 1920 in Mount Vernon, New York and raised mostly in White Plains, Richter was a Sarah Lawrence alumna who earned a Ph.D. in Psychology from the University of Connecticut in 1959 ("Memorial" 1974). After obtaining her degree, Richter taught physiology and biology at Vassar College for several years. She joined the Sarah Lawrence faculty in 1963, where she held key administrative positions including Dean of Graduate Studies
(Richter, Academic Personnel File). From 1960 to 1968 she also served as principal investigator for a series of research grants from the US Public Health Service, and published articles on induced thirst and calcium deprivation in laboratory rats (Richter, Vita). According to her colleague and close friend Jacquelyn Mattfeld, then Dean of the College, Richter had a profound interest in human and animal variation from the standpoints of both behavioral psychology and evolutionary biology (Mattfeld 2008). She was also a vocal advocate of women's education who was eager to expand career options for returning female students, particularly in the health sciences.

Richter's approach to genetic counseling was prescient and original. She foresaw a budding niche for specialists trained in laboratory, statistical, and psychological aspects of human genetics. As she told the Sarah Lawrence Alumnae Magazine in 1971, "Researchers are making new breakthroughs in genetics all the time...but there is nobody to pass these services on to patients. There is a tremendous gap at this point between knowledge and service" (Happenings 1971, p. 5). Richter's objective was to bridge that gap by training smart and caring women who could communicate effectively with patients, many of whom would consult genetics clinics as intended or already devoted mothers.

In addition to being perceptive, Richter was daring and persistent. Although she had few, if any, connections to medical geneticists, Richter boldly sent letters to genetics sections in universities, hospitals and state health departments across the country in order to assess the need for a master's program in genetic counseling. In return, she received scattered praise and much criticism. One physician told her, "I am very fearful that the results of the program you are outlining will be a disaster," another warned her to "stay away from this area," and yet another exclaimed that her plan was "nonsensical" and a "totally unrealistic approach" (Richter, Correspondence 1969a, January to April, May to December). Over and over again, her respondents, in what can be understood as a paternalistic form of professional gate-keeping, averred that only $\mathrm{PhDs}$ or MDs legitimately could do genetic counseling. Almost all the experts consulted by Richter viewed genetic counselors as mere appendages - aides, helpers, assistants, or at most, associates - charged with finishing the low priority duties for which busy physicians had no time or inclination. Even if encouraging, nearly all the letters expressed scant faith in the capacity of Sarah Lawrence, a small liberal arts college, to adequately institute such a program. Many people might have given up after encountering such resistance, but Richter was buoyed not disheartened by the responses, negative and positive, that she received. Frequently, Richter replied to scathing letters with a cheerful thank you and update on how the program was proceeding. 
Given Richter's research interests in the social behavior of animal populations enduring stress, it is not surprising that she framed the need for genetic counseling in terms of population management and biological enhancement. Notably, Richter delineated the key reasons for the program's creation as "the increase of illnesses by inherited diseases; the sizeable proportion of our population suffering from mental or emotional disturbances; and the problems created by overpopulation" (Richter 1968a, p. 1). Drafting her proposal the same year that Paul Erhlich (1968) published the best-selling and apocalyptic The Population Bomb, Richter expressed both stridency and naiveté about the possibilities of regulating the "load of genetic disease that is accruing in our population" (Richter 1968b, p. 12). Exhibiting faith in the curative power of modern medicine, extrapolated from the wonders of antibiotics and vaccines and a few apparent triumphs in the treatment of metabolic disorders, Richter viewed genetic counseling as a means to reducing hereditary diseases and persuading individuals to make sensible choices about reproduction for their benefit and that of the population at large.

Richter couched her pilot proposal in neo-Malthusian and eugenically-oriented language. She expressed unambiguous ideas about appropriate and inappropriate breeding, normality and defectiveness, as well as optimism about the prospects of genetic control. In this sense, Richter followed in the footsteps of a preceding generation of medical geneticists such as Sheldon Reed, Nash Herndon, and Lee Raymond Dice who had occupied the nebulous domain of genetic counseling from the 1940 s to the 1960 s with one foot solidly in the eugenics camp (Comfort 2006; Paul 1997). These medical geneticists were all active members of the American Society for Human Genetics and the American Eugenics Society. They viewed genetic counseling as a central component of disease prevention that, in most instances, could eliminate deleterious traits from the population while helping families to avoid unnecessary suffering and shame.

Ultimately however, Richter's position was characterized more by metamorphosis than continuity. She initiated Sarah Lawrence's program as the eugenics era of the early to mid twentieth century was in the final phase of eclipse. Although she initially accepted eugenic rationales and never abandoned the creed of prevention, in the end Richter supported a brand of genetic counseling that emphasized private decision-making, reproductive choice and budding concepts of bioethics. In large part, this reflected Richter's interest in patient care, an area in which she had virtually no experience but much insight. For example, in a lecture before the New England Association of Nurses at Boston College in May 1970 , Richter stated that one goal of medical genetics was prevention, such that "everyone can be born free of birth defects." Nevertheless, the paramount aim was improved and dedicated patient care, which she touted as the "the primary driving force for all of us who are contributing or who wish to contribute to this field" (Richter 1970). As her program moved from the page to the clinic, Richter's focus shifted accordingly, away from philosophical declarations about reproduction and population to the logistics of fieldwork placements and the challenges of conveying complex genetic information to concerned patients.

\section{Location, Location, Location: Bronxville to Manhattan, 15 Miles}

Richter was a maverick, but did not persevere in a vacuum. She certainly would not have been able to get the program off the ground without the backing of Sarah Lawrence's administration. Founded in 1926 as a progressive women's college, Sarah Lawrence possessed a mixture of affluent students, focus on individualized education, flexible curriculum and deep commitment to service learning (Coleman 2000; Walters 2003). Since the 1930s, field work in community sites had been central to the college experience of Sarah Lawrence students. The genetic counseling program resonated with that creative tradition of experimentation. Furthermore, the faculty operated in a fairly unstructured environment that granted them considerable leeway in educational design (Marks 2007). Rather than rein Richter in, her superiors nurtured and championed her ideas. Richter's most important collaborator and confidante was Mattfeld, with whom Richter regularly brainstormed about new directions for women's education in science and medicine (Davis 2008; Mattfeld 2008). Mattfeld, a savvy administrator who later became a Provost at Brown University, repeatedly emphasized Richter's notable academic talents and personal style to colleagues and potential grantors alike (Marks 2007). For instance, in a grant request to the Commonwealth Fund, Mattfeld heralded Richter as "one of those rare persons who combine originality with an uncommon gift for teaching, and genuine administrative ability" (Mattfeld to Newton 1968). Richter also benefited considerably from her warm relationship with Raushenbush, who was pivotal to the nascence, development and financial stability of the program. Thanks in large part to the efforts of Mattfeld and Raushenbush, the program started with a $\$ 20,000$ grant from the Babcock Foundation. Richter built on this initial investment and established a funding pattern that the program's subsequent director Joan Marks, a psychiatric social worker and Sarah Lawrence alumna, emulated with tremendous success. For example, in 1970 the program was awarded a multi-year grant from the National Institutes of Health-Manpower Training Division and in 1974 a 3-year student training fellowship from the March of Dimes (Grant Awards 1969-1992). 
The college's proximity to New York City, an epicenter of leading hospitals and, more important, recently established genetics clinics, was also integral to the program's achievements. It is difficult to imagine any other site in the USA (perhaps Boston as a distant second) that could have allowed for such extensive and varied internship experiences for genetic counseling students. Richter astutely took advantage of Sarah Lawrence's strategic location. During the 3 years that she directed the program, Richter forged productive relationships with clinical geneticists and allied physicians throughout New York City. Once convinced of the viability of Richter's plan, this nexus became instrumental to the program's consolidation and increasing visibility to the medical genetics community at large.

One of Richter's closest New York City partners was Jessica Davis, a pediatrician at Albert Einstein College of Medicine Hospital who had become interested in genetics during her medical training at Columbia University (Davis 2008). Davis, also an alumna of an elite women's college (Wellesley) and a tireless promoter of female scientists, was a natural ally for Richter. Indeed, Davis agreed, despite a more than full-time clinical and research load, to co-direct the program with Marks during 1972-1973 when Richter took a sabbatical to pursue research on sex differentiation and, unbeknownst to many, battle a recurrence of breast cancer (Mattfeld 2008).

In spring 1969, Richter contacted Davis for advice on how to get Sarah Lawrence's program off the ground. Davis, who immediately was taken with Richter's persona and vision, concurred that an exciting opening existed for master's level genetic counselors. Based on her clinical work in pediatric genetics, Davis suggested that Richter model the genetic counselor on the medical social worker, an idea first discussed by Reed (who coined the term "genetic counseling") in his 1955 book Counseling in Human Genetics. Unlike Reed, however, who thought strongly that only MDs and $\mathrm{PhDs}$ adequately could do what he called "genetic social work," Davis and Richter were convinced that the master's level genetic counselor could combine the strengths of medical social work with rigorous training in the life sciences to distinguish herself as an independent health care provider. Kurt Hirschhorn, a pediatrician and research geneticist at Mt. Sinai who Richter also consulted, recommended Lynn Godmilow, a social worker who had enhanced his clinical practice and patient care as a guiding example (Hirschhorn 2008).

Davis was particularly helpful to Richter; she helped her build "a bridge to the genetics community, which was small and very inward" and not necessarily eager for educational innovation (Davis 2008). Reiterating a suggestion made by Mattfeld, Davis urged Richter to identify advisors that could provide feedback and help the program insinuate itself into an enlarging network of medical genetics clinics and services. Sarah Lawrence's first trio of advisorsHirschhorn, Arthur Robinson of the University of Denver, and John Littlefield of Massachusetts General Hospital in Boston-offered sage counsel and conferred scientific and clinical authority to the program.

That proximity to New York City was central to the evolution of Sarah Lawrence's program is illustrated by reviewing field placement sites from 1969 to 1972. Half were clinics in Manhattan that spearheaded the use of new procedures like amniocentesis and maintained state-of-theart laboratories where enzyme analyses of diseases like Tay-Sachs could be performed. Outside the city limits, Richter established internships at two state institutions and one community children's health clinic. At Creedmor State Hospital, Richter received a warm welcome from John Whittier, who let Sarah Lawrence's students participate in consultations with and observe the clinical care of Huntington Disease patients (Richter, Notes on meetings with Whittier). Just two out-of-state sites, at Massachusetts

Table 1 Initial Clinical Placement and Internship Sites for Sarah Lawrence's Genetic Counseling Program, 1969-1972

\begin{tabular}{lll}
\hline Place and unit & Location & Facilitating geneticist/physician \\
\hline Mt. Sinai Hospital, Medical Genetics & New York City & Kurt Hirschhorn \\
New York Cornell Medical Center & New York City & Alexander G. Bearn \\
The Albert Einstein College of Medicine Hospital, & New York City & Harold Nitowsky and Jessica Davis \\
Genetic Counseling Program & & Ernest Lieber \\
Beth Israel Hospital & New York City & John Rainer \\
New York State Psychiatric Institute & New York City & John Whittier \\
Creedmoor State Hospital & Creedmor, New York & Lawrence R. Shapiro \\
Letchworth Village, Cytogenetics Lab & Thiells, NY & Milton Reisner \\
Westchester County Community Mental Health Board, & Mt. Vernon and Peekskill, NY & \\
Special Children's Clinic & & John W. Littlefield \\
Massachusetts General Hospital, Genetics Clinic & Boston, MA & Henry L. Nadler \\
Children's Memorial Hospital, Genetics Clinic & Chicago, IL & \\
\hline
\end{tabular}


General Hospital and Chicago Children's Memorial Hospital, offered summer placements due to the enthusiasm of, respectively, Littlefield and Henry Nadler.

Manhattan was also where Sarah Lawrence students received training in clinical genetics. When the initial group of ten women joined the Sarah Lawrence program in fall 1969, they attended most classes, including Mendelian and Molecular Genetics and Social Psychiatry, at Sarah Lawrence, but studied medical genetics at the Albert Einstein School of Medicine Hospital with Harold Nitowsky and Jessica Davis. In addition, an arrangement with Hirschhorn allowed students to participate in medical conferences at Mt. Sinai Hospital (Heimler, person communication 2008, June 18; Details of the Proposed Program 1967-1972). Table 1 lists the sites where Sarah Lawrence students obtained clinical experience during the academic year and the summer. Furthermore, many in the program's initial graduating classes so impressed their mentors that they secured jobs where they had interned or were recommended for positions at genetics clinics in the New York area (Human Genetics Program Description of Jobs 1973).

\section{Transforming Technologies and Evolving Attitudes}

At a 1972 American Society of Human Genetics symposium on genetic counseling held in Philadelphia, James V. Neel, the founder of the Human Genetics Department at the University of Michigan, told his colleagues, "suddenly, genetic counseling is transformed from a sophisticated guessing game in which the counselor usually engaged only after an unfortunate genetic event, to a situation" where one "identifies the high-risk family to suitable surveys or directed tests prior to the first conception and monitors each pregnancy for genotype of child" (Neel 1973, p. 1). Neel's quote illustrates the major shift in human genetics that occurred in the late 1960s and early 1970s, when genetic counseling could extend beyond the tools of pedigree charting and the calculation of Mendelian probabilities to determinations about carrier status and the identification of some chromosomal and metabolic conditions. This transformation in diagnostic capability was propelled by the development of new procedures and techniques in reproductive medicine and medical genetics.

Foremost among these was amniocentesis, which had been utilized by some obstetricians starting in the 1940s to relieve patients with polyhydramnios and, on occasion, to perform biochemical testing of maternal-fetal $\mathrm{Rh}$ compatibility. By the 1950s advances in the culturing of fetal cells allowed amniocentesis to be combined with cytogenetic techniques like karyotyping for the purposes of chromosomal and biochemical analysis (Cowan 2008). In 1959, physicians in Denmark performed the first prenatal diag- nosis for sex chromatin on a pregnant woman who knew from previous births that she was a carrier of hemophilia, an X-linked trait. Utilizing amniocentesis, the clinicians determined that she was carrying a female child, information that resulted in her choosing to continue rather than terminate the pregnancy. This same year, Jérôme Lejeune, a French pediatric geneticist identified trisomy 21 as the cause of Down Syndrome; this discovery soon was followed by the detection of an increasing number of chromosomal abnormalities through laboratory research with cultured, and eventually, uncultured fetal cells.

Richter's recognition of these advances, and their implications for patients, prompted her to design the genetic counseling program. Even so, she was ahead of time. Indeed, the year Richter initiated Sarah Lawrence's program, the World Health Organization issued a report on genetic counseling which warned that amniocentesis was hazardous and "involves a serious risk" to the development of the fetus (World Health Organization 1969, p. 10). While only 300 amniocentesis procedures were performed between 1967 and 1971 in the USA, after a series of clinical trials that assured high levels of safety and diagnostic accuracy, that figure jumped to 3,000 in 1974 (Cowan 2008). Coinciding with the growth of genetic counseling programs in the 1970s, amniocentesis became a standard part of prenatal care, usually recommended for women over 35 or with family histories of various genetic conditions (Resta 1997, 2002).

Combined with ultrasound and fetal surgery, amniocentesis raised awareness of birth defects as diseases that could be prevented or better managed among neonates and children. Increasingly, the public was learning about these scientific advances through the media, which often sought to explain how these new technologies worked and considered their implications for health professionals, patients, and society at large (Hixson 1967; Sullivan 1970). As long-time New York Times columnist Jane Brody wrote in 1971 (p. 41), "prenatal diagnosis - the detection of birth defects at a time when the fetus can still be abortedis drastically changing the nature and potential of genetic counseling throughout the country."

Moreover, in a far-reaching social change, genetic information could be weighed in decisions about whether or not to legally terminate a pregnancy. In 1970, 3 years before the US Supreme Court decision Roe v. Wade, New York became the first state in the country to decriminalize abortion, permitting women to obtain abortions pursuant on informed consent and as long as performed no later than the 24th week after conception (Harris et al. 1975; Mohr 1979). Thus, Sarah Lawrence's inaugural cohort of genetic counseling students started their clinical training as abortion became feasible for patients, and at a time when the feminist health and reproductive rights movement had augmented acceptance of and access to birth control. 
These developments led some to prophesize about a new epoch of genetic engineering, a prospect that was fiercely debated among geneticists, philosophers, lawyers and ordinary citizens. Such concerns were integral to the emergence of bioethics, as an area of philosophical inquiry and as a set of concepts applied to clinical medicine. Master's level genetic counselors were settling into their new jobs at clinics around the country as hearings in the US Congress addressed the violations of human rights and bodily integrity, not to mention racism and discrimination against the disabled, that occurred during the 40-year long Tuskegee Syphilis Study and with the involuntary sterilization of thousands of minority and poor women in the late 1960s. Cognizance of these abuses, as well as the dark and disturbing shadow of Nazi genocide, helped to frame approaches to the goals and limits of genetic counseling. For instance, Arno Motulsky of the University of Washington, who became an advisor to Sarah Lawrence's program in 1973, published a penetrating article that same year that evaluated the ethical responsibilities of physicians with regard to reproductive and genetic medicine. Looking back at an often ugly past and forward to an uncharted future, he wrote "enforced sterilization should be strongly rejected" and "open discussion and freedom from coercion are the best guarantees for ultimate success" (Motulsky 1973, 319, 327). Motulsky encapsulated the ethos of genetic counselors, whose duty was to "put the interests of the patient and his family before those of society and the state. The genetic counselor pursues medical and not eugenic objectives" (Motulsky 1973, 318).

Although Richter arrived at genetic counseling partly because of anxieties about overpopulation, she was a steely supporter of individual reproductive choice. Revealing in this regard is Richter's correspondence with Lejeune, a devout Catholic who opposed abortion and solemnly stated in his 1969 William Allan Memorial Award Lecture to the American Society of Human Genetics, that "even the most disinherited belongs to our kin" (Lejeune 1970, 128). In response to the existential question - what is human?- that Lejeune considered in his lecture, Richter posed the counter-question - what is not human?-in a letter to him. She told Lejeune that she believed that "parents have the right not to run the risk of having two, or three or five children with cystic fibrosis, but that society at this point should not legislate that no one should have a child with cystic fibrosis." In Richter's perspective, which was aligned with the feminist health movement, reproductive decisions were private and should not be dictated by the state (Richter to Lejeune 1970). Once thrown into the moral dilemmas being deliberated by genetic health professionals at the time, Richter, pondered in letters and lectures the assumptions intrinstic to the disease prevention model, how to communicate genetic risk with sensitivity and scientific accuracy, and what function public agencies should play in genetic testing and genetic counseling.

To this day, the influence of the formation of master's level genetic counseling programs on the emergence and priorities of bioethics remains a largely overlooked topic. Yet grappling with the bioethical dilemmas raised by genetic testing was something genetic counseling students and practitioners did (and continue to do) every day. At the outset of Sarah Lawrence's program many students wanted forums to discuss the moral conundrums they confronted, especially with regard to conveying information to parents about probable or identified defects in their child. In January 1972, Richter responded to students who expressed "a desire to discuss the responsibility of exerting influences on the lives of others" by organizing a workshop on the ethical, moral and social implications of genetic counseling (Richter, Memorandum 1972). Five years after she became director Marks bolstered Richter's preliminary attempts by adding a four semester sequence titled "Issues in Clinical Genetics," which studied patients' rights, women's health, family dynamics, and medical sociology, to the formal curriculum (Marks, personal communication 2008, June 24; Issues in Clinical Genetics, 1979-1980). After Richter died of breast cancer in November 1974, the program blossomed under the under the leadership of Marks, who served as director until 1998. During that quarter century, Marks enhanced the psychosocial component of the program, became a leading figure in the medical genetics community, and was instrumental to the field's rising national prominence as it earned the hallmarks of a genuine profession.

\section{Pioneers and Guinea Pigs}

One of the reasons why Sarah Lawrence's program was able to thrive was that its high-quality students fit, and helped to carve, an emerging niche very well. In Richter's words, the students were "a most unusual bunch," "all highly motivated, deeply concerned to serve and highly intelligent" (Richter to Andy 1969). Furthermore, they soon acquired skills that were in great demand as genetic services became a routine facet of medical care. Nevertheless, reflecting Richter's interest in the returning students affiliated with the Center for Continuing Education, the cohorts that entered between 1969 and 1972 often were attracted to the program because they were women whose family responsibilities meant they could work limited hours. As Richter wrote in 1970, "since the women have homes to keep most are on a part-time study schedule. This sets the pace they will probably be keeping when they have completed their training and are working in Medical Genetics Centers" which "are only open one day a week" 
(Richter, History). Of the inaugural cohort (which ultimately included 12 students as two joined the cohort in January 1970), all of them were mothers. Only one was not married and under 26 years of age. At the very beginning of the program, this profile enabled Sarah Lawrence's genetic counseling students and graduates to situate themselves in clinics with little fanfare or professional rivalry. Physicians found it fairly easy to accept these new nurse-like figures that they regularly referred to patronizingly as "girls." However, this pattern helped to set the stage for the feminization of genetic counseling, a process that resulted in the field being undervalued in terms of salary and status. Nestled in these founding trends are clues to understanding how genetic counselors could both be so appreciated for their skills and have to fight so hard for professional recognition and respect. The field's heated battles of the 1970s and 1980s, over the title of "genetic associate" (which both Richter and Marks favored) versus "genetic counselor" (which won the day), and what professional body could and should oversee board certification for genetic counselors reveals the salience of these contradictions.

Even as this early pattern was leaving a discernible imprint, the composition of the program changed markedly. Marks quickly recognized that while Richter's preferred student-a white-middle aged mother from Westchester County-might become an excellent genetic counselor, so too could a wide range of applicants (Marks, personal communication 2008, June 24). Under Marks' direction, the cohorts became more diverse in terms of age and region of origin. By the mid1970 s, $62 \%$ of the incoming class was under 26 ; it included students from across the country and small but steady number of men ("Sarah Lawrence Human Genetics Graduate Program, Student Statistics" 1977; Marks and Richter 1976). Whereas Sarah Lawrence's entire inaugural cohort was local, almost all from Westchester County, by 1975 nearly half were from outside the New York metropolitan area, a figure that reached $73 \%$ the following year. The 1976 and 1977 entering classes counted students that hailed from California, Maine, Virginia, Ohio and Massachusetts ("Sarah Lawrence Human Genetics Graduate Program, Student Statistics" 1977). This soon became the norm, not just at Sarah Lawrence, but around the country.

Pathways to master's level genetic counseling grew in the early 1970s when programs were established at the University of Pittsburgh (1971), University of Denver (1971), Rutgers University (1972), University of California at Berkeley (1973) and the University of California at Irvine (1973). These sister programs broadened and diversified the field in terms of region, curriculum and clinical training. Like at Sarah Lawrence, they were often the result of one or two enterprising faculty members who saw the need for an interdisciplinary master's program at her or his institution. As such, these programs found assorted academic homes in their universities. For example, Berkeley's program was housed in the Health and Medical Sciences program, established in 1972 upon the recommendation of a Chancellor's Advisory Committee. Organized to be intellectually flexible, this program sought to address "the broader question of health, rather than medicine alone" and fostered the interdisciplinary training of health professionals (University of California, Berkeley 1977). At Berkeley, the Genetic Counseling Option was one of three graduate tracks in Health and Medical Sciences that included a joint medical program with the University of California at San Francisco and a mental health program in collaboration with San Francisco's Mt. Zion hospital. In contrast to Sarah Lawrence, where students rotated among dozens of different facilities in and around the New York area, for Berkeley students the clinical experience was centralized principally at the University of California, San Francisco's clinics across the bay, an arrangement facilitated chiefly by Charles Epstein (Epstein 2008; Weil 2007). In the eyes of its founders, Berkeley's genetic counseling program resonated well with a holistic approach to health care delivery, a match that explains why Berkeley would come to distinguish itself with a focus on psychosocial training.

One of the leitmotivs that emerges in oral history interviews with faculty and students involved in the early years of master's degree genetic counseling was their willingness to take a considerable risk on an unknown field that offered little concrete promise in terms of future position or pay. In the words of Audrey Heimler, a member of Sarah Lawrence's inaugural cohort, she and her peers were "guinea pigs and pioneers," a sentiment echoed by many of her contemporaries around the country (Heimler 2007). Michael Begleiter was one of six students that enrolled in the program at Rutgers University (housed in the Douglass College for women) started by Marian L. Rivas. Begleiter also iterated that his cohort consisted of "pioneers" whose mutual immersion in a fledging enterprise helped to forge a deep bond that has endured to the present (Frolich et al. 2007). In a related vein, genetic counselors who matriculated from programs in the early 1970s frequently describe their relationship to the field as a "calling" that enabled them to combine their various interests and talents - in genetics, health care, human psychology and reproductive issues-into a multifaceted whole. June Peters, a peer of Begleiter, pithily sums up a common feeling: "it was just like I was made for this field" (Frolich et al. 2007).

\section{Legacies and Reflections}

Although she directed Sarah Lawrence's program for just three brief years, Richter left a lasting impression on 
colleagues and students alike. Davis remembers that in her soft-spoken and gentle manner, Richter energetically pursued her plan, winning many converts along the way. For example, through her persuasive personality and steadfast conviction, Richter brought Motulsky, who at first glance was quite critical of her plan, to her side (Davis 2008; Motulsky to Richter 1969). Mattfeld remembers Richter as "an amazing teacher, adored by her students, and absolutely creative in the classroom," who ostensibly enjoyed the rare position of being universally liked by her colleagues at Sarah Lawrence (Mattfeld 2008). Looking back at her experience in Sarah Lawrence's first cohort, Heimler exclaims that Richter "lit a fire under us," as she inspired students about the exciting future that awaited them in clinical genetics (Heimler 2007).

Just as the story of the founding of the genetic counseling program at Sarah Lawrence College evokes powerful memories, it also raises intriguing questions about the relationship between past and present. For instance, the racial, ethnic, and class homogeneity of the early cohorts still characterizes genetic counselors, who overwhelmingly are white middle-class women. According to the NSGC's 2006 Professional Status Survey, 91\% of genetic counselors self-identify as Caucasian, $5 \%$ as Asian, $1 \%$ African American, and 2\% Hispanic. Only 4\% are men (Parrott and Del Vecchio 2007). One of the pressing concerns voiced by many of the genetic counselors interviewed for this project is how to alter this composition to more closely match the demographics of patients and keep pace with an increasingly multiracial US society. What is disheartening for many is that despite concerted efforts over the years, including minority fellowships, educational outreach, and Spanish language training, this career personality has proven exceedingly difficult to crack. According to Barbara Biesecker, a University of Michigan alumna who directs the Johns Hopkins University-National Human Genome Research Institute genetic counseling program, the field faces a real crisis point when it comes to diversity. For Biesecker, one of the key problems is that genetic counselors "haven't articulated a contemporary working hypothesis for why so few under-represented minorities or men are drawn to the profession" (Biesecker 2007). Perhaps tracing the field's roots back to Sarah Lawrence can help to elucidate how white middle-class women became the profession's core demographic. However, it is also important to remember there is nothing inevitable about this dynamic. Ideally, knowledge of the past can productively inform genetic counselors as they chart their future. Diane Baker, who founded the University of Michigan's genetic counseling program in 1979, reminds us that genetic counseling "was a career that was great for people with disrupted lives"(Baker 2008). Although Richter's desired student body appears very monochromatic by today's standards, Baker's comment suggests that the field's core versatility could make it very alluring to twenty-first century non-traditional students, a group that encompasses heterogeneous racial, ethnic, class, and linguistic backgrounds.

Another legacy of the quiet revolution that occurred at Sarah Lawrence in 1969 pertains to debates about the role of eugenics in the history of genetic counseling. There is no denying that when Richter started the program she was motivated by anxieties over overpopulation and irresponsible reproduction. It was not uncommon for her to highlight eugenic goals - of population improvement through the elimination of defective genes - in her rationale for the Sarah Lawrence program. However, as Richter witnessed the on-the-ground practice of genetic counseling, which revolved around patients and their families, Richter's overarching focus became the individual not the population. In a 1970 lecture, Richter stated that the most appropriate way to look at medical genetics was not as large-scale disease prevention but as "patient care, regardless of its evolutionary effects" (Richter 1970). Unlike the medical geneticists who preceded her in genetic counseling, such as Reed and Herndon, Richter never belonged to any eugenics groups nor endorsed any formal eugenics agendas. According to Mattfeld, Richter shunned membership in organizations with any kind of political or social agenda, even Planned Parenthood, whose mission she supported (Mattfeld 2008). Rather that fret about what label to attach to Richter during a compressed time period when her thinking was rapidly evolving, it is more instructive to track how she navigated ideas about human improvement, disease prevention, and the social aspects of reproductive choice. These are all topics that today's genetic counselors wittingly or unwittingly face when discussing options for, or the results of, genetic testing and screening. In retrospect, Richter, never one to shy away from intense subjects, is to be commended for approaching philosophical concerns and ethical dilemmas head on, even as 21 st century readers might balk at some of her proclamations.

\section{Conclusion}

The birth of Sarah Lawrence's program is illuminating for many reasons. On the most basic level, this is a dramatic and often overlooked story in twentieth century medicine and society with a compelling cast of characters, above all Richter, who died as her dream was becoming a reality. Furthermore, the initial years of the program coincided with an extraordinary convergence of phenomena, including second-wave feminism, the decriminalization of abortion, discoveries in medical genetics, the expansion of prenatal services and genetic testing, and changing attitudes toward 
the physician-patient relationship. Finally, genetic counselors can learn about the foundational strengths and weaknesses of their profession by traveling back four decades, when the genetic counselor acquired her job description and embarked on the exhilarating challenge of securing a valued home in the patchwork landscape of clinical genetics.

Acknowledgements The research for this article was supported by a National Library of Medicine-National Institutes of Health Publication Grant and a National Endowment for the Humanities (Healthcare and Humanities Initiative) Fellowship. I would like to thank Robert Resta, Joan Marks, Jon Weil, June Peters, Michael Begleiter, Audrey Heimler, Jessica Davis, Kurt Hirschhorn, Charles Epstein, Jacquelyn Mattfeld, Barbara Biesecker, Diane Baker, Wendy Uhlmann, and two anonymous reviewers for their contributions to and insightful comments on this essay.

\section{References}

Anderson, T. H. (1996). The movement and the sixties. New York: Oxford University Press.

Baker, D. (2008). Interview conducted by the author. January 16.

Bender, M. (1969). A new breed of middle-class women emerging. New York Times, p. 34, March 17.

Bergsma, D. (Ed.) (1970). Genetic counseling with particular reference to anticipatory guidance and the prevention of birth defects. Birth Defects: Original Articles Series, 6(1). Baltimore: Williams and Wilkins for the National Foundation-March of Dimes, May.

Biesecker, B. (2007). Interview conducted by the author. February 1.

Brady, T. F. (1969). Mrs. Raushenbush emerges unscarred in Sarah Lawrence confrontation. New York Times, (p. 70), March 23.

Brody, J. E. (1971). Prenatal diagnosis is reducing risk of birth defects. New York Times (pp. 41, 53), March 3.

Coleman, S. R. (2000). To promote creativity, community, and democracy: The progressive colleges of the 1920s and the 1930s. Doctoral dissertation. Columbia University.

Comfort, N. (2006). 'Polyhybrid heterogeneous bastards': Promoting medical genetics in America in the 1930s and 1940s. Journal of the History of Medicine and Allied Sciences, 61(4), 415-455. doi:10.1093/jhmas/jr1001.

Cowan, R. S. (2008). Heredity and hope: The case for genetic screening. Cambridge: Harvard University Press.

Davis, J. (2008). Interview conducted by the author. March 14.

Details of the Proposed Program (1967-1972). Finances and fundraising/ grants. Human genetics graduate program records. Bronxville, New York: Sarah Lawrence College.

Ehrlich, P. (1968). The population bomb. New York: Ballantine Books.

Epstein, C. (2008). Interview conducted by the author. May 15.

Frolich, G., Begleiter, M., Peters, J. \& Baty, B. (2007). Interview conducted by the author.

Grant Awards to the Human Genetics Program (1969-1992). Finances and fundraising/grants. December 18.

Happenings (1971). Sarah Lawrence Alumnae Magazine (p. 5). Spring.

Harris, D., O'Hare, D., Pakter, J., \& Nelson, F. G. (1975). Legal abortion 1970-1971 - the New York City experience. American Journal of Public Health, 63(5), 409-418.

Heimler, A. (1997). An oral history of the National Society of Genetic Counselors. Journal of Genetic Counseling, 6(3), 315-336. doi:10.1023/A:1025680306348.
Heimler, A. (2007). Interview conducted by the author. October 13. Hirschhorn, K. (2008). Interview conducted by the author. March 8.

Hixson, J. R. (1967). Forecasts from the womb. New York Times (p. 56).

Human Genetics Program Description of Jobs held by Graduates. (1973). Administrative files, statistics. Human genetics graduate program records. Bronxville, New York: Sarah Lawrence College.

Issues in Clinical Genetics (1979-80). Curriculum and fieldwork files. Human genetics graduate program records. Bronxville, New York: Sarah Lawrence College, January 19.

Lejeune, J. (1970). On the nature of men. American Journal of Human Genetics, 22(2), 121-128.

Marks, J. H. (2007). Interview conducted by the author. January 19.

Marks, J. H., \& Richter, M. L. (1976). The genetic associate: A new health professional. American Journal of Public Health, 66(4), $388-390$.

Mattfeld, J. (2008). Interview conducted by the author. April 17.

Mattfeld, J. to Newton, Q. (1968). Finances and fundraising/grants files. Commonwealth fund, 1968-69, Human Genetics Graduate Program Records. Bronxville, New York: Sarah Lawrence College.

Memorial Dec. 21 for Dr. Richter (1974, December 5). The Providence Journal (p. B2). Letter, December 21.

Mohr, J. C. (1979). Abortion in America: The evolution of national policy. New York: Oxford University Press.

Motulsky, A. (1973). Brave new world? Ethical issues in prevention, treatment and research of human birth defects. In A. Motulsky \& W. Lentz. (Eds.), Proceedings of the Fourth International Conference, Vienna, Austria, 1971, September 2-8. Birth Defects, International Congress Series 310 (pp. 311-328).

Motulsky, A., \& Richter, M. L. (1969). Board of advisors, members, Arno Motulsky, Human Genetics Graduate Program Records. Bronxville, New York: Sarah Lawrence College Letter, April 9.

Neel, J. (1973). The coming of age of genetic counseling. Contemporary Genetic Counseling. Birth Defects, Original Article Series, 9 (4), 1-4. White Plains, New York: The National FoundationMarch of Dimes.

Parrott, S., \& Del Vecchio, M. (2007). Boston Information Solutions. National Society of Genetic Counselors, Inc. Professional Status Survey 2006 (February), available online at www.nsgc.org.

Paul, D. (1997). From eugenics to medical genetics. Journal of Policy History, 9(1), 96-116.

Reed, S. C. (1955). Counseling in medical genetics. Philadelphia: Saunders.

Resta, R. G. (1997). The first prenatal diagnosis of a fetal abnormality. Journal of Genetic Counseling, 6(1), 81-83.

Resta, R. G. (2002). Historical aspects of genetic counseling: Why was maternal age 35 chosen as the cut-off for offering amniocentesis? Medicina nei Secoli Arte E Scienza, 14(3), 793811.

Richter, M. L. (1968a). Health sciences in social change: Pilot projects at Sarah Lawrence College, Richter Correspondence, Human Genetics Program Proposal, 1968-69, Human Genetics Graduate Program Records. Bronxville, New York: Sarah Lawrence College.

Richter, M. L. (1968b). The effects of over-population on behavior: The biologist's view. Sarah Lawrence Alumnae Magazine (pp. 11-15).

Richter, M. L. (1969a). Richter correspondence, general, human genetics graduate program records. Bronxville, New York: Sarah Lawrence College January to April, May to December.

Richter, M. L. (1969b). Notes on meetings with Whittier. Richter correspondence, Creedmor State Hospital, New York, 1969 1973, Human genetics graduate program records. Bronxville, New York: Sarah Lawrence College Archives December 10; 1970, February 2; 1970, July 10; 1970, October 22; 1970, October 26. 
Richter, M. L. (1969c). Notes on symposium on genetic counseling, National Foundation-March of Dimes, 29 January 1969 at the Commodore Hotel, N.Y.C., Richter Correspondence, Conferences, Human Genetics Graduate Program Records. Bronxville, New York: Sarah Lawrence College.

Richter, M. L. (1970). A talk to the New England Association of Nurses at Boston College. Richter speeches, human genetics graduate program records. Bronxville, New York: Sarah Lawrence College May 22.

Richter, M. L. (1972). Memorandum. Richter correspondence, human genetics graduate program. Bronxville, New York: Sarah Lawrence College January 12.

Richter, M. L. (no date). Academic personnel file. Bronxville, New York: Sarah Lawrence College.

Richter, M. L. (no date). History, human genetics, program, human genetics graduate program records. Bronxville, New York: Sarah Lawrence College.

Richter, M. L. Vita. Richter Biographical Files, ca. 1970-1976, human genetics graduate program records. Bronxville, New York: Sarah Lawrence College.

Richter, M. L., \& Whipple, J. B. (1972). A revolution in the education of women: Ten years of continuing education at Sarah Lawrence College. Bronxville, New York: Sarah Lawrence College.

Richter, M. L., \& Andy (no last name), (1969). Richter correspondence, general, human genetics graduate program records. Bronxville, New York: Sarah Lawrence College Letter, July 9.

Richter, M. L., \& Lejeune, J. (1970). Richter correspondence, general 1970-1973, human genetics graduate program re- cords. Bronxville, New York: Sarah Lawrence College Letter, September 21.

Richter, M. L., \& Raushenbush, E. (1969). Richter correspondence, general, May to December 1969, human genetics graduate program records. Bronxville, New York: Sarah Lawrence College Letter, October 6.

Rosen, R. (2000). The world split open: How the women's movement changed America. New York: Penguin.

Sarah Lawrence College Human Genetics Graduate Program (1977). Administrative files-statistics-1969-1979, Human genetics graduate program records. Bronxville, New York: Sarah Lawrence College December.

Sarah Lawrence Quiet (1969). New York Times (p. 22). March 15.

Stock, R. W. (1969). Will the baby be normal? The genetic counselor tries to find the answer by translating the biological revolution into human terms (pp. SM25-SM34). New York Times. March 23.

Sullivan, W. (1970). Wider detection of prenatal flaws expected to spur abortions. New York Times, p. 11, June 30.

University of California, Berkeley (1977). Health and Medical Sciences Program 1977/78. September.

Walters, S. (2003). An individual education: the foundations of Sarah Lawrence College. The Westchester Historian, 79(4), $100-112$.

Weil, J. (2007). Interview conducted by the author. November 20.

World Health Organization (1969). Genetic counseling. World Health Organization technical report series, no. 416. Geneva: World Health Organization. 